\title{
WHICH TYPE OF DESIGN PROJECT IS BEST: NARROW AND DETAILED OR BROAD AND CONCEPTUAL?
}

\author{
Ralph O. Buchal \\ Western University \\ rbuchal@eng.uwo.ca
}

\begin{abstract}
Engineering design is an essential part of the engineering curriculum, and it is important to select projects with appropriate scope and challenge to develop the desired skills subject to constraints on time, student ability and available resources. This paper considers two types of projects typically encountered in capstone design: detailed design projects, and conceptual design projects. Detailed design projects usually have a goal of constructing and testing a physical prototype, and the main focus is on CAD modeling, detailed analysis, engineering drawings, manufacturing processes, prototype fabrication, and testing. Conceptual design projects focus on the conceptual design stages, and typically do not result in a prototype. These projects are more open-ended, and focus on problem definition, background research, order-of-magnitude analysis, numerical simulation, technical and economic feasibility, and consideration of nontechnical aspects including impact on society and the environment. This paper compares and contrasts the two types of projects in terms of their characteristics, and evaluates them based on the CEAB Graduate Attributes. Both types of projects provide valuable and complementary design experience, and each type emphasizes different attributes.
\end{abstract}

Keywords: capstone design, conceptual design, detailed design, CEAB Graduate Attributes

\section{INTRODUCTION}

Engineers are involved in many types of design projects, which vary in scope and complexity. It is important to identify appropriate design experiences for undergraduate engineering students.

There is still no universally accepted definition of engineering design, but there is general consensus about some of the attributes of design. The Canadian Engineering Accreditation Board (CEAB) defines design as follows:
"Engineering design integrates mathematics, the basic sciences and complementary studies in developing elements, systems and processes to meet specific needs. It is a creative, iterative and often open-ended process subject to constraints, which may be governed by standards or legislation to varying degrees, depending on the discipline. These constraints may relate to economic, health, safety, social or other pertinent factors [1].

The corresponding $\mathrm{CEAB}$ graduate attribute defines design as:

An ability to design solutions for complex, open-ended engineering problems and to design systems, components or processes that meet specified needs with appropriate attention to health and safety risks, applicable standards, economic, environmental, cultural and societal considerations [1].

The following statements about the nature of engineering design are generally accepted:

- Design is a purposeful activity directed at meeting a need, solving a problem, achieving a goal or satisfying a set of objectives.

- The design process is subject to constraints.

- Engineering design involves the application of engineering knowledge, usually from different disciplines.

- Design is an iterative, open-ended, creative process.

- Design involves problems with multiple possible solutions.

- Design involves evaluation and decision-making to select the best solution.

- Design decisions are validated by analysis and testing.

- Economic, social and environmental impact must be considered in engineering design.

- Designers must deal with lack of complete knowledge or information.

- Design involves uncertainty and risk. 
- Design builds on what has been done previously.

- Design strives to increase the "ideality" of a technical system by improving the positive aspects (e.g. satisfaction of needs), and/or reducing the negative aspects (e.g. cost, environmental impact).

Furthermore, it is also agreed that the following are NOT engineering design:

- Building a prototype without engineering analysis

- Building a prototype by trial and error "tinkering"

- Sketching fanciful design ideas without engineering validation

- Inventing

\section{STUDENT DESIGN PROJECTS}

All engineering students in Canada are required to develop competence in design, as one of the CEAB graduate attributes. Specifically, CEAB requires that:

The engineering curriculum must culminate in a significant design experience conducted under the professional responsibility of faculty licensed to practise engineering in Canada, preferably in the jurisdiction in which the institution is [1].

$\cdots$

The significant design experience is based on the knowledge and skills acquired in earlier work and it preferably gives students an involvement in team work and project management [1].

Ideally, all engineering students can be exposed to all aspects of realistic engineering design projects. In practice, design experience is subject to several constraints, including time, ability and resources.

\subsection{Time Constraints}

Capstone design projects must be completed within one academic year or less, by a small team of students. Capstone design is just one of several courses in the final year, so students only devote a small fraction of their time to the project. The realistic time that can be dedicated to a capstone project by a team of three working 8 hours/week for 26 weeks is about 80 person days, or 4 person months. This significantly restricts the scope of projects that are possible.

Projects are also constrained by unavoidable delays in ordering parts, scheduling the construction of prototypes, scheduling access to test facilities, waiting for responses from vendors, etc.

As a result of these constraints, it is rarely possible for a project to go from conceptual design through to prototype construction and testing, at least without cutting corners somewhere.

\subsection{Ability Constraints}

Due to lack the expertise and experience, students take much longer to complete a project than more experienced engineers. This is part of the learning process, but further limits the realistic project scope.

For projects involving prototypes, students either construct the prototype themselves, or have the prototype constructed to their specifications by skilled technicians. While the hands-on experience is important, few students have the skills to construct a high quality prototype.

\subsection{Resource Constraints}

Lack of resources and funding severely constrain the scope of construction and testing that is possible within a design project. Prototypes constructed by skilled technicians typically cost at least several hundred to several thousand dollars.

\subsection{Types of Projects}

As with many other aspects of design education, there is no general agreement about the type of project that is best suited to engineering education. Due to the constraints already discussed, it is impossible to have projects that have both breadth and depth, so a compromise is required. We can consider two types of projects representing polar extremes: detailed design projects, and conceptual design projects.

\section{DETAILED DESIGN PROJECTS}

Detailed design projects typically result in a working prototype. Given the constraints of time, ability and resources, such projects are necessarily limited to fairly simple artifacts. These projects are typically small, narrow and focused. They usually result in a discrete and fairly simple artifact. These projects develop skills in detailed design, including detailed analysis, engineering drawings, manufacturing processes, testing, cost analysis, and so on. The focus here is on the practical details of design.

\subsection{Example: Design of Wheel Assemblies for Formula SAE Racecar}

Student design competitions like Formula SAE provide an excellent detailed design experience with a strong emphasis on prototype construction and testing. A recent Western project involved the design and construction of new suspension uprights and hubs for the 2013 car. The goal was to improve the previous design to make it lighter and easier to manufacture and maintain. The suspension 
geometry was fixed, and the loads were well known. The main design activities included:

- Selection of materials and manufacturing processes

- CAD modeling

- $\quad$ FEA for different load cases

- Iterative refinement of geometry to minimize weight subject to allowable stresses

- $\quad$ Bearing selection and sizing

- $\quad$ Preparation of engineering drawings

- $\quad$ Sourcing of purchased components

- Fabrication by students and sponsors

- $\quad$ Testing and installation on car

This project was based very closely on the established mechanical engineering curriculum, including solid mechanics, kinematics and dynamics, materials selection, manufacturing processes, CAD, CAM, FEA and mechanical components design.

\section{CONCEPTUAL DESIGN PROJECTS}

Conceptual design projects tend to be abstract, and lack practical detail. Examples of such a project are the conceptual design of a sustainable personal mobility system $[2,3,4]$, or the design of a renewable energy system for a remote mine [5]. Projects like this rely on extensive background research, systems thinking, awareness of complex interactions, and consideration of sociotechnical and environmental factors. The goals are to achieve a better understanding of the technical and economic feasibility, and the benefits to customers (e.g. to satisfy a need) and to society (e.g. to improve living conditions, environmental sustainability, etc.). These projects rely on order-of-magnitude modeling and analysis. Prototypes and detail drawings do not make sense for projects of this type.

\subsection{Example: Avalon Renewable Energy Alternatives}

Avalon Rare Metals Inc. is planning a new mine site in Northwest Territories. Power for remote mines is normally provided by diesel generators. The cost of diesel fuel is very high, and diesel power has significant environmental impact. Avalon has approached engineering students at Western and other universities to evaluate renewable energy alternatives for power generation and energy storage, as well as energy efficiency measures, to find an optimal integrated solution to minimize cost and environmental impact.

The essential characteristics of the project are described by Bill Mercer, VP Exploration, Avalon Rare Metals Inc. [5]:
It is recognised that the total power supply investigation is complex and in some cases, solid technical information is either lacking, or perhaps not totally reliable as the source is a company which is developing the new power equipment. However, such a research topic is very valuable due to the increasing emphasis on sustainable development and the high fuel consumption of traditional diesel generation.

This potential research project for engineering students would bring together the following areas among others:

1. Electrical power system design.

2. Construction of wind towers, solar panel arrays.

3. Chemical engineering of battery systems.

4. Financial modeling of alternatives.

5. Transportation of diesel, wood pellets.

6. Building engineering design.

7. Computer control systems for electrical integration.

8. Understanding of greenhouse gas production, potential GHG levies, etc

9. Environmental impacts of various energy systems on biodiversity, emissions, etc.

Thus it can be seen that the project is highly suited for engineering students to work in diverse teams to seek solutions to challenging problems. Given the controversial nature of renewable energy, both politically and environmentally, with many people divided into pro and con camps, this will also expose the students to a subject that demands critical and objective thinking.

The main design activities in this project were background research to understand the problem and technologies, collecting and analyzing data, and mathematical modeling and simulation of alternative scenarios. This project involved no CAD modeling or prototype construction, and the scope was well beyond the traditional boundaries of mechanical engineering. The intention was to have teams of mechanical, electrical, civil and chemical students work together on different aspects. In practice, we had only mechanical and chemical students, and only the mechanical students worked together.

\section{A COMPARISON OF PROJECT TYPES}

It is helpful to compare and contrast conceptual versus detailed design projects based on qualitative attributes on 
a number of dimensions, as summarized in table. No value judgment is implied by these attributes. For example, "theoretical" is not better or worse than "practical”.

Table 1. Detailed versus conceptual design projects.

\begin{tabular}{|l|l|}
\hline Detailed design projects & Conceptual design projects \\
\hline Detail orientation & Conceptual orientation \\
\hline Practical & Theoretical \\
\hline Exact & Order-of-magnitude \\
\hline Small scale & Large scale \\
\hline Components & Systems \\
\hline Physical prototype & Conceptual framework \\
\hline Experiments and testing & Computer simulation \\
\hline Engineering drawings & Schematics and diagrams \\
\hline Focus on function & Focus on feasibility \\
\hline Technical & Sociotechnical \\
\hline Specific & General \\
\hline Narrow & Broad \\
\hline Deep & Shallow \\
\hline Routine & Innovative \\
\hline Rules & Judgment \\
\hline Reduction & Integration \\
\hline Known & Unknown \\
\hline
\end{tabular}

\section{MAPPING TO CEAB GRADUATE ATTRIBUTES}

Capstone design is one of the best places to develop and demonstrate the CEAB Graduate Attributes. As well as being required for program accreditation, the Graduate Attributes are an excellent set of objectives and criteria for capstone projects. The following sections discuss the two types of projects in terms of graduate attributes.

\subsection{A knowledge base for engineering}

Demonstrated competence in university level mathematics, natural sciences, engineering fundamentals, and specialized engineering knowledge appropriate to the program.

Both types of projects have ample opportunity to demonstrate this attribute. The knowledge required for conceptual design projects is typically more interdisciplinary and general than the deep specialized knowledge required for detailed design.

\subsection{Problem analysis}

An ability to use appropriate knowledge and skills to identify, formulate, analyze, and solve complex engineering problems in order to reach substantiated conclusions.
Detailed design projects typically make use of wellknown analytical methods, in well understood domains. Typical techniques include standard engineering calculations, FEA, engineering experimentation, etc. Conceptual design projects are often more open-ended, and different analytical techniques may be required, e.g., Monte Carlo simulation. Conceptual design projects have more uncertainty, and skill in approximation and estimation is usually required.

\subsection{Investigation}

An ability to conduct investigations of complex problems by methods that include appropriate experiments, analysis and interpretation of data, and synthesis of information in order to reach valid conclusions.

Detailed design projects often have opportunities for experimentation and testing of prototypes. Conceptual design projects generally rely more on mathematical models and simulation experiments. Proper experimental methods are required in both cases.

\subsection{Design}

An ability to design solutions for complex, open-ended engineering problems and to design systems, components or processes that meet specified needs with appropriate attention to health and safety risks, applicable standards, economic, environmental, cultural and societal considerations.

Conceptual design projects are typically more openended than detailed design projects. Economic, social and environmental considerations are usually central to conceptual design projects, whereas they are typically an afterthought if considered at all in detailed design projects.

\subsection{Use of Engineering Tools}

An ability to create, select, apply, adapt, and extend appropriate techniques, resources, and modern engineering tools to a range of engineering activities, from simple to complex, with an understanding of the associated limitations.

The predominant tools in detailed design projects are CAD and CAE. On the other hand, conceptual design uses different tools including spreadsheet analysis, Monte Carlo simulation, etc. Different types of projects use different tools.

\subsection{Individual and Team Work}

An ability to work effectively as a member and leader in teams, preferably in a multi-disciplinary setting. 
Conceptual projects are typically more multidisciplinary, including disciplines outside of engineering. However, it is difficult to establish and manage truly interdisciplinary design teams composed of students from different departments and even faculties.

\subsection{Communication Skills}

An ability to communicate complex engineering concepts within the profession and with society at large. Such abilities include reading, writing, speaking and listening, and the ability to comprehend and write effective reports and design documentation, and to give and effectively respond to clear instructions.

Both types of projects require and develop communication skills. Conceptual projects may also require communication with other disciplines, including non-engineers.

\subsection{Professionalism}

An understanding of the roles and responsibilities of the professional engineer in society, especially the primary role of protection of the public and the public interest.

Conceptual design projects typically consider public interest and public safety more directly than most detailed design projects.

\subsection{Impact of engineering on society and the environment}

An ability to analyse social and environmental aspects of engineering activities. Such abilities include an understanding of the interactions that engineering has with the economic, social, health, safety, legal, and cultural aspects of society; the uncertainties in the prediction of such interactions; and the concepts of sustainable design and development and environmental stewardship.

Impact of engineering on society and the environment is usually central to conceptual design projects, whereas it is usually secondary in detailed design projects if considered at all. Some detailed design projects have safety requirements explicitly specified, e.g. Formula SAE safety requirements.

\subsection{Ethics and equity}

An ability to apply professional ethics, accountability, and equity.

This attribute remains poorly defined and hard to measure. It is included here for completeness.

\subsection{Economics and project management}

An ability to appropriately incorporate economics and business practices including project, risk and change management into the practice of engineering, and to understand their limitations.

Detailed design projects are usually limited to the management of the project itself, and budgeting of the prototype. Conceptual design projects often include consideration of long-term feasibility plans, and project economic feasibility. Conceptual design typically involves more risk and uncertainty than detailed design.

\subsection{Life-Long Learning}

An ability to identify and to address their own educational needs in a changing world, sufficiently to maintain their competence and contribute to the advancement of knowledge.

Most detailed design projects require knowledge from the previous engineering curriculum. Conceptual design projects are often interdisciplinary, and require knowledge not taught in engineering courses. Background research in detailed design projects aims to increase depth of knowledge, whereas conceptual design increases breadth of knowledge.

Table 2 is a subjective and qualitative assessment of the degree to which each type of project addresses the Graduate Attributes. Each attribute is rated from weak $(*)$ to strong $(* * * *)$ in each graduate attribute. While each rating is of course subject to debate, the message here is that conceptual design projects often develop the CEAB Graduate Attributes more directly and strongly than most detailed design projects. Both types of projects are suitable as capstone experiences, with each type focusing on different attributes and skills. It is important to review the definition and scope of every design project to maximize the development of the Graduate Attributes.

Table 2. Rating conceptual and detailed design projects using CEAB Graduate Attributes. *-very weak, ${ }^{\star * \star *}$-very strong.

\begin{tabular}{|l|l|l|}
\hline & Detailed design & $\begin{array}{l}\text { Conceptual } \\
\text { design }\end{array}$ \\
\hline Knowledge base & $\begin{array}{l}* * * \\
\text { Narrow and deep }\end{array}$ & $\begin{array}{l}* * * * \\
\text { Broad and } \\
\text { shallow }\end{array}$ \\
\hline $\begin{array}{l}\text { Problem } \\
\text { Analysis }\end{array}$ & $\begin{array}{l}* * * \\
\text { Detailed and } \\
\text { exact } \\
\text { CAD and FEA }\end{array}$ & $\begin{array}{l}\text { Or* } \\
\text { Order of } \\
\text { magnitude } \\
\text { Spreadsheet } \\
\text { models }\end{array}$ \\
\hline Investigation & $* * *$ & $\begin{array}{l}* * * \\
\text { Simulations }\end{array}$ \\
\hline Design & Experiments & $* * *$ \\
\hline
\end{tabular}




\begin{tabular}{|c|c|c|}
\hline & $\begin{array}{l}\text { Detailed } \\
\text { component }\end{array}$ & $\begin{array}{l}\text { Conceptual } \\
\text { system }\end{array}$ \\
\hline $\begin{array}{l}\text { Engineering } \\
\text { tools }\end{array}$ & $\begin{array}{l}* * * \\
\text { CAD, FEA }\end{array}$ & $\begin{array}{l}* * * \\
\text { Spreadsheets, } \\
\text { simulations }\end{array}$ \\
\hline $\begin{array}{l}\text { Individual and } \\
\text { team work }\end{array}$ & $\begin{array}{l}* * * \\
\text { Small, single- } \\
\text { disciplinary team } \\
\text { Sometimes part } \\
\text { of a larger team }\end{array}$ & $\begin{array}{l}* * * \\
\text { More multi- } \\
\text { disciplinary, } \\
\text { teams from } \\
\text { different } \\
\text { disciplines }\end{array}$ \\
\hline Communications & $* * *$ & $\begin{array}{l}* * * * \\
\text { Communication } \\
\text { between } \\
\text { disciplines }\end{array}$ \\
\hline Professionalism & $\begin{array}{l}* \\
\text { Safety may be } \\
\text { specified by } \\
\text { competition } \\
\text { requirements }\end{array}$ & $\begin{array}{l}* * * * \\
\text { Public safety and } \\
\text { public needs } \\
\text { dominate }\end{array}$ \\
\hline $\begin{array}{l}\text { Impact on } \\
\text { society }\end{array}$ & $\begin{array}{l} \\
\text { Usually not } \\
\text { considered }\end{array}$ & $\begin{array}{l}* * * * \\
\text { Dominant theme } \\
\text { of project }\end{array}$ \\
\hline $\begin{array}{l}\text { Economics and } \\
\text { project } \\
\text { management }\end{array}$ & $\begin{array}{l}* * * \\
\text { Focus on } \\
\text { implementation } \\
\text { Multi-week } \\
\text { timelines } \\
\text { Small budget for } \\
\text { prototype } \\
\text { Part of larger } \\
\text { project }\end{array}$ & $\begin{array}{l}* * * \\
\text { Focus on } \\
\text { feasibility and } \\
\text { planning } \\
\text { Multi-year } \\
\text { timelines } \\
\text { Multimillion } \\
\text { dollar budgets }\end{array}$ \\
\hline $\begin{array}{l}\text { Lifelong } \\
\text { learning }\end{array}$ & $\begin{array}{l}* * \\
\text { Reviewing and } \\
\text { supplementing } \\
\text { existing } \\
\text { disciplinary } \\
\text { knowledge }\end{array}$ & $\begin{array}{l}* * * * \\
\text { Interdisciplinary, } \\
\text { extensive } \\
\text { research and } \\
\text { learning needed }\end{array}$ \\
\hline
\end{tabular}

\section{DISCUSSION AND CONCLUSIONS}

There are many engineering educators who believe that capstone projects should focus on detailed design, with preparation of engineering drawings and fabrication and testing of prototypes. These are important kinds of projects, but they are not the only kind. Conceptual design projects that do not result in drawings or prototypes are equally valid. Both types of projects can be equally strong in application of knowledge base, problem analysis, investigation, design and use of tools. Conceptual design projects are often stronger in impact on society and lifelong learning. All projects should be carefully selected and defined to strengthen the elements addressing the Graduate Attributes. Conceptual design projects must have sufficient engineering content, and detailed design projects should have more aspects of impact on society and economics if possible. In many cases, these elements can be added fairly easily. For example, a detailed design project might consider the economics of producing a product in volume, and include a Life Cycle Assessment to determine the environmental impact of the product.

\section{References}

[1] Accreditation Criteria and Procedures, Canadian Engineering Accreditation Board, Canadian Council of Professional Engineers, 2012.

[2] Ralph O. Buchal, "Designing the car of the future", in Proc. Canadian Engineering Education Association (CEEA) Inaugural Conference, Kingston Ontario, June 7-9, 6 pp., 2010.

[3] Ralph O. Buchal, A. Day, J.C. Robinson, "Design of a sustainable personal mobility system (SPMS)", in Proc. Canadian Engineering Education Association (CEEA) 2011 Conference, St. Johns Newfoundland, June 6-8, 6 pp., 2011.

[4] Ralph O. Buchal, “A Holistic, Interdisciplinary Approach to the Design of a Sustainable Personal Mobility system”, in Proc. Canadian Engineering Education Association (CEEA) 2012 Conference, Winnipeg Manitoba, June 17-20, 6 pp., 2012.

[5] Bill Mercer, Energy Alternatives - Nechalacho Project, NWT, Avalon Rare Metals Inc., 2012. 